\title{
Effects of long-range aerosol transport on the microphysical properties of low-level liquid clouds in the Arctic
}

\author{
Quentin Coopman ${ }^{1,2}$, Timothy J. Garrett ${ }^{1}$, Jérôme Riedi ${ }^{2}$, Sabine Eckhardt ${ }^{3}$, and Andreas Stohl ${ }^{3}$ \\ ${ }^{1}$ Department of Atmospheric Sciences, University of Utah, Salt Lake City, UT, USA \\ ${ }^{2}$ Laboratoire d'Optique Atmosphérique, Université de Lille/CNRS, Lille, France \\ ${ }^{3}$ Norwegian Institute for Air Research, Kjeller, Norway
}

Correspondence to: Quentin Coopman (quentin.coopman@ed.univ-lille1.fr)

Received: 1 October 2015 - Published in Atmos. Chem. Phys. Discuss.: 12 November 2015

Revised: 19 March 2016 - Accepted: 29 March 2016 - Published: 14 April 2016

\begin{abstract}
The properties of low-level liquid clouds in the Arctic can be altered by long-range pollution transport to the region. Satellite, tracer transport model, and meteorological data sets are used here to determine a net aerosol-cloud interaction $\left(\mathrm{ACI}^{\text {net }}\right)$ parameter that expresses the ratio of relative changes in cloud microphysical properties to relative variations in pollution concentrations while accounting for dry or wet scavenging of aerosols en route to the Arctic. For a period between 2008 and 2010, $\mathrm{ACI}^{\text {net }}$ is calculated as a function of the cloud liquid water path, temperature, altitude, specific humidity, and lower tropospheric stability. For all data, $\mathrm{ACI}^{\text {net }}$ averages $0.12 \pm 0.02$ for cloud-droplet effective radius and $0.16 \pm 0.02$ for cloud optical depth. It increases with specific humidity and lower tropospheric stability and is highest when pollution concentrations are low. Carefully controlling for meteorological conditions we find that the liquid water path of arctic clouds does not respond strongly to aerosols within pollution plumes. Or, not stratifying the data according to meteorological state can lead to artificially exaggerated calculations of the magnitude of the impacts of pollution on arctic clouds.
\end{abstract}

\section{Introduction}

Due to growing concentrations of greenhouse gases and complex feedback processes, the Arctic region has warmed approximately 2 times faster than the global average (Serreze and Francis, 2006; Serreze et al., 2009; Richter-Menge and Jeffries, 2011), a trend that is anticipated to continue through this century (Yoshimori et al., 2013; Overland and Wang,
2013). Further, the Arctic is not pristine, even if it is remote from industrialized areas and major aerosol sources. Midlatitude aerosols can be transported to northern latitudes in relatively high concentrations when precipitation rates are low and there are strong temperature inversions that inhibit vertical mixing (Sirois and Barrie, 1999; Law and Stohl, 2007; Quinn et al., 2007; Law et al., 2014). The origins of arctic haze tend to be pollution from Eurasia (Shaw, 1995; Stohl, 2006; Shindell et al., 2008; Ancellet et al., 2014), and boreal forest fires in North America, Eastern Europe, and Siberia (Stohl, 2006; Stohl et al., 2007). Between spring and summer, the atmosphere becomes cleaner due to an increase in wet scavenging (Garrett et al., 2010).

Such aerosols have the potential to alter cloud properties in the Arctic (Garrett and Zhao, 2006; Lance et al., 2011). On one hand, thin low-level clouds with more numerous smaller droplets can radiate more longwave radiation thereby warming the surface (Garrett et al., 2002, 2004; Garrett and Zhao, 2006). On the other, polluted clouds can reflect more sunlight, leading to a cooling effect (Lubin and Vogelmann, 2007). Zhao and Garrett (2015) found that seasonal changes in surface radiation associated with haze pollution range from $+12.2 \mathrm{~W} \mathrm{~m}^{-2}$ in February to $-11.8 \mathrm{~W} \mathrm{~m}^{-2}$ in August. Annually averaged, the longwave warming and shortwave cooling nearly compensate, although the seasonal timing of the forcings may have implications for rates of sea ice melt (Belchansky et al., 2004; Markus et al., 2009).

The influence of aerosols on cloud microphysical properties is often quantified using an indirect effect (IE) or aerosol-cloud interaction (ACI) parameter that expresses the ratio of relative changes in cloud microphysical properties to 
variations in pollution concentrations, most typically aerosol index, the aerosol optical depth, the aerosol concentration, or the cloud condensation nucleus $(\mathrm{CCN})$ concentration (Feingold et al., 2001; Feingold; 2003b). Where the parameter is expected to decrease with increasing aerosols or cloud condensation nuclei (e.g., the effective radius), the ratio is multiplied by -1 so that the IE or ACI is positive.

Garrett et al. (2004) used ground-based retrievals of clouddroplet effective radius and surface measurements of dried aerosol light scattering from Barrow (Alaska) to obtain a value for the cloud-droplet effective radius ACI that lies between 0.13 and 0.19 . Satellite measurements show that ACI values for cloud-droplet effective radius range from 0.02 to 0.20 for midlatitude continental clouds (Nakajima et al., 2001; Feingold, 2003a; Lohmann and Feichter, 2005; Myhre et al., 2007) and from 0.03 to 0.15 for midlatitude oceanic clouds (Bréon et al., 2002; Sekiguchi, 2003; Kaufman et al., 2005; Myhre et al., 2007; Costantino and Bréon, 2013; Wang et al., 2014). Satellite instruments have the advantage of providing data over large spatial scales, however satellite retrievals of aerosol concentrations are normally obtained from air columns close to the analyzed cloud. The assumption is made that plumes are horizontally homogeneous both within and without the cloud, and that they are vertically colocated with the cloud top (Nakajima et al., 2001; Feingold et al., 2001; Sekiguchi, 2003). For large-scale cloud studies, this method potentially introduces bias since it is not obvious that pollution should be uniform for different meteorological regimes.

Colocating satellite cloud retrievals with pollution tracer output from a chemical transport model offers an alternative approach for assessing the effect of pollution on clouds (Berg et al., 2011; Lance et al., 2011; Tietze et al., 2011). Cloud microphysical properties and pollution concentrations can be estimated at the same time, location, and meteorological regime (Schwartz et al., 2002; Kawamoto et al., 2006; Avey et al., 2007). Active tracers experience both sources and sinks through wet scavenging, dry deposition, and chemical reactions that can be difficult to accurately model. Passive pollution tracers, on the other hand, are determined only by source emission strength and subsequent dilution. An example of a passive tracer is carbon monoxide (CO), which is a combustion byproduct that correlates with the anthropogenic CCN close to pollution sources (Longley et al., 2005). Since both are found in pollution plumes, CO can serve as a passive proxy for $\mathrm{CCN}$ that is relatively straightforward to model. A difference is that, unlike $\mathrm{CCN}, \mathrm{CO}$ is unaffected by wet and dry scavenging. In the absence of scavenging, a linear relation exists between $\mathrm{CCN}$ and $\mathrm{CO}$ and it should be possible to see changes in clouds when $\mathrm{CO}$ concentrations are high. However, if $\mathrm{CCN}$ have been scavenged from pollution plumes, then the observed sensitivity of clouds to the pollution plumes should be expected to be low. Thus, passive tracers serve as an indicator of the net effect of pollution plumes on clouds that accounts for the effect of scavenging during transport en route to the clouds themselves.

More generally, the primary controls on cloud microphysical properties are not aerosols but rather meteorological conditions during cloud formation (Chang and Coakley, 2007; Brenguier and Wood, 2009; Kim et al., 2008; Painemal et al., 2014; Andersen and Cermak, 2015). For example, a reduced stability of the environmental temperature profile can allow for enhanced cloud-droplet growth through increasing convection (Klein and Hartmann, 1993). This would be expected to lead to greater mixing of the aerosols with the cloudy air and greater aerosol impacts on cloud microphysical properties (Chen et al., 2014; Andersen and Cermak, 2015). Also, in the Arctic during the winter, pollution plumes from Asia are often associated with higher values of potential temperature than pollution plumes from Europe (Stohl, 2006). Thus, the observed impact of pollution plumes on clouds may be correlated with a particular meteorological regime.

Using the approach of colocating a passive tracer from a tracer transport model with satellite observations, Tietze et al. (2011) presented an analysis of pollution-cloud interactions over the Arctic from March to July 2008. Anthropogenic and biomass burning aerosol pollution was represented using a CO passive tracer in the FLEXPART (FLEXible PARTicle dispersion model) tracer model (Stohl et al., 2005) as a proxy. CO was colocated with POLDER-3 (POLarization and Directionality of the Earth's Reflectance) and MODIS (MODerate-resolution Imaging Spectroradiometer) observations. Tietze et al. (2011) showed that the sensitivity of liquid-cloud-droplet effective radius $\left(r_{\mathrm{e}}\right)$ and optical depth $(\tau)$ to pollution has a maximum around the freezing point, and that the sensitivity decreases for both higher and lower temperatures. The optical depth was generally up to 4 times more sensitive than the effective radius. Their results also suggested that biomass burning pollution has a smaller yet significant impact on liquid cloud microphysical properties than anthropogenic pollution, and that the ACI parameters depend on altitude, LWP, and temperature.

Our study extends the Tietze et al. (2011) research by adding 2 years of data, 2009 and 2010, and in addition to temperature, stratifying the results by lower tropospheric stability (LTS) and atmospheric specific humidity (Matsui et al., 2006; Mauger and Norris, 2007). Our results highlight the importance of considering meteorological conditions when assessing the aerosol impact on cloud microphysical properties to show that $r_{\mathrm{e}}$ and $\tau$ have similar sensitivities to pollution.

\section{Data}

The analyses in this study are based on a colocation of satellite retrievals of cloud properties, tracer transport model simulations of pollution locations and concentrations, and reanalysis data sets for meteorological fields. 


\subsection{Satellite cloud property retrievals}

In this study we used two instruments, both part of the Atrain mission (Stephens et al., 2002). The MODIS instrument on board the Aqua satellite measures radiation in 36 different spectral bands with central wavelength from 400 to $14400 \mathrm{~nm}$ in wavelength. For the effective radius, optical depth, and cloud top temperature we use Collection 5 Level-2 products (Platnick et al., 2003; King and Platnick, 2006). Regarding the technique applied for computation of the MODIS Level-2 products cloud top temperature is derived from the $11 \mu \mathrm{m}$ infrared band. Cloud-droplet effective radius $\left(r_{\mathrm{e}}\right)$ and optical depth $(\tau)$ are retrieved from simultaneous cloud reflectance measurements in three water-absorbing bands $(1.6,2.1,3.7 \mu \mathrm{m})$ and three nonabsorbent bands $(0.65$, $0.86,1.2 \mu \mathrm{m}$ ) (Platnick et al., 2003). The pixel resolution of the retrievals at nadir is $1 \mathrm{~km} \times 1 \mathrm{~km}$ for cloud microphysics and $5 \mathrm{~km} \times 5 \mathrm{~km}$ for cloud top temperature.

The POLDER-3 camera on the PARASOL satellite platform (Polarization \& Anisotropy of Reflectances for Atmospheric Sciences coupled with Observations from a Lidar) captures a wide field of view through spectral, directional, and polarized measurements of reflected sunlight (Fougnie et al., 2007). Multidirectional observations allow for a pixel to be observed from up to 16 different view angles. The instrument measures radiance in 9 spectral channels between 443 and $1020 \mathrm{~nm}$, including three polarized channels at 490, 670 , and $865 \mathrm{~nm}$. POLDER-3 cloud microphysical properties retrievals have a $36 \mathrm{~km} \times 36 \mathrm{~km}$ spatial resolution. Cloud top pressure is derived from the cloud oxygen pressure (Bréon and Colzy, 1999). Cloud top pressure retrieved by POLDER3 appears to be a better proxy for low-level cloud height than MODIS cloud top pressure derived using a thermal signature assuming a given temperature profile (Buriez et al., 1997; Weisz et al., 2007; Tietze et al., 2011; Desmons et al., 2013).

To determine the cloud thermodynamic phase we use a combination of MODIS and POLDER-3 measurements. The algorithm takes advantage of multiangle polarization data, shortwave, thermal infrared, and visible measurements to retrieve a thermodynamic phase index $\Phi$ between 0 for liquid clouds and 200 for ice clouds with varying degrees of confidence (Riedi et al., 2010). Figure 1 shows the distribution of the thermodynamic phase index for clouds between 200 and $1000 \mathrm{~m}$ and between 1000 and $2000 \mathrm{~m}$ altitude from 2008 to 2010 over a region with latitudes greater than $65^{\circ}$. We observe different modes in the phase index corresponding to liquid clouds with $\Phi$ lower than 70 , clouds with undetermined phase, mixed phase, or multiple cloud layers, for which $\Phi$ lies between 70 and 140, and ice clouds with $\Phi$ greater than 140 .

\subsection{Anthropogenic pollution tracer fields}

For determining anthropogenic pollution tracer fields, we use the Lagrangian particle dispersion model FLEXPART

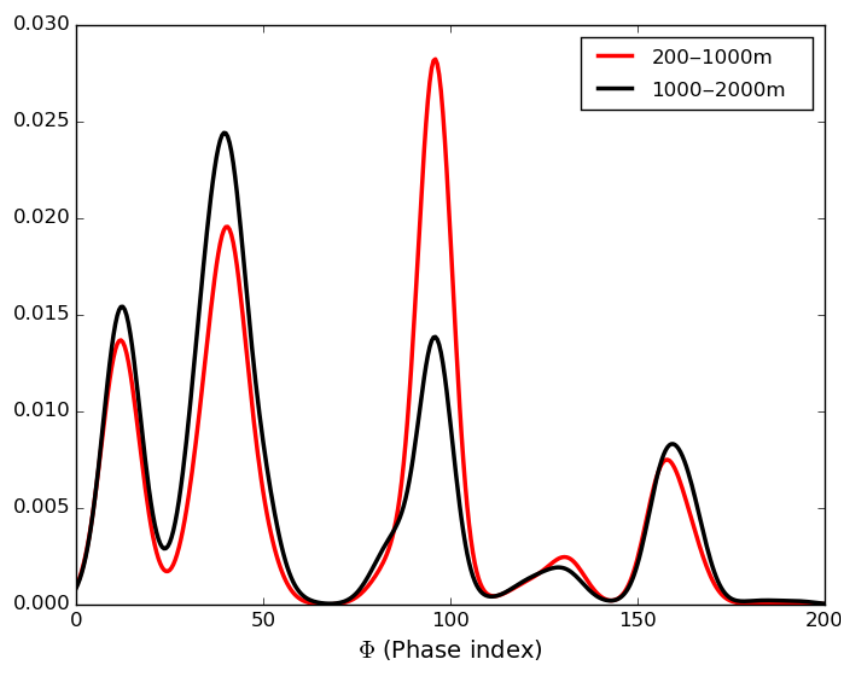

Figure 1. Normalized cloud thermodynamic phase index frequency distribution from the POLDER-MODIS algorithm, for pixels with the phase-index SD less than 10. Colors represent different cloud altitudes, between 200 and $1000 \mathrm{~m}$ in red and between 1000 and $2000 \mathrm{~m}$ in black.

(Stohl et al., 1998, 2005). The model is driven with 3-hourly operational analysis wind fields from the European Centre for Medium-Range Weather Forecasts (ECMWF) with 91 model levels and a horizontal resolution of $1^{\circ} \times 1^{\circ}$. We use the same simulations as described by Stohl et al. (2013), which consider a black-carbon tracer undergoing removal processes, two fixed-lifetime black-carbon tracers, and a carbon monoxide (CO) tracer. The $\mathrm{CO}$ tracer used for this study is considered as passive in the atmosphere but is removed from the simulation 31 days after emission, thus focusing the simulation on "fresh" pollution. For the $\mathrm{CO}$ emissions, ECLIPSE (Evaluating the CLimate and Air Quality ImPacts of Short livEd pollutants) version 4.0 emission data (Klimont et al., 2016; Stohl et al., 2015) are used. For the anthropogenic emissions considered here, the ECLIPSE emissions are based on the GAINS (Greenhouse gas-Air pollution Interaction and Synergies) model (Amann et al., 2011). The emissions are determined separately for every year of this study and, notably, include gas flaring emissions, which have been shown to be important for black carbon in the Arctic (Stohl et al., 2013). Emissions from the residential sector are temporally disaggregated using a heating degree-day approach (Stohl et al., 2013).

Studies that have used FLEXPART CO concentration fields $\left(\chi_{\mathrm{CO}}\right)$ have found satisfactory agreement between model output and measurements (Stohl, 2006; Paris et al., 2009; Hirdman et al., 2010; Sodemann et al., 2011; Stohl et al., 2013, 2015; Eckhardt et al., 2015). In the Alaskan Arctic for the day of 18 April 2008, Warneke et al. (2009) described a slope of 0.9 for a linear fit between FLEXPART model output of $\chi_{\mathrm{CO}}$ and airborne measurements of $\mathrm{CO}$ with a least-squares correlation coefficient of 0.63 . 
Table 1. Cloud products, pollution tracer, atmospheric reanalysis used in this study with the corresponding spatial and temporal resolution.

\begin{tabular}{lll}
\hline Parameter(s) & From & Resolution(s) \\
\hline $\begin{array}{l}\text { Cloud parameters }\left(T, r_{\mathrm{e}}, \tau\right) \\
\text { CO tracer concentration from anthropogenic sources }\end{array}$ & MODIS, POLDER-3 & Spatial resolution: $36 \mathrm{~km}^{2}$ \\
& & Spatial resolution: $1^{\circ} \times 2^{\circ}$ \\
Specific humidity, temperature profile & ERA-I (ECMWF) & Temporal resolution: $3 \mathrm{~h}$ \\
& & Spatial resolution: $1.5^{\circ} \times 1.5^{\circ}$ \\
& & Temporal resolution: $6 \mathrm{~h}$ \\
\hline
\end{tabular}

The FLEXPART model outputs used here have a temporal resolution of $3 \mathrm{~h}$ and a spatial resolution of $1^{\circ} \times 2^{\circ}$ (in latitude and longitude) divided into 9 different vertical levels. FLEXPART CO concentration $\left(\chi_{\mathrm{CO}}\right)$ output is provided in units of $\mathrm{mg} \mathrm{m}^{-3}$ but converted to units of ppbv (parts per billion by volume) to remove the atmospheric pressure dependence. Since the focus here is on the effect of anthropogenic pollution on clouds, only FLEXPART spatial bins where anthropogenic sources comprise more than $80 \%$ of total CO concentrations are considered for comparison with cloud properties.

\subsection{Meteorological data}

ERA-Interim (ERA-I) reanalysis data from ECMWF (Berrisford et al., 2009) extend from 1989 to the present with an improved version released in 2011 (Dee et al., 2011). The temporal resolution is $6 \mathrm{~h}$ at 60 pressure levels. Reanalysis data from ERA-I show good agreement with satellite retrievals and aircraft data for cloud fraction and cloud radiative forcing in the Arctic (Zygmuntowska et al., 2012). Wesslén et al. (2014) analyzed ERA-I data with the Arctic Summer Cloud Ocean Study (ASCOS) campaign measurements in 2008 and calculated biases of about $1.3^{\circ} \mathrm{C}, 1 \%$, and $-1.5 \mathrm{hPa}$, respectively, for temperature, relative humidity, and surface pressure; root mean square errors of about $1.9^{\circ} \mathrm{C}, 3.7 \%$, and $8.7 \mathrm{hPa}$, respectively; and correlation coefficients of approximately 0.85 for temperature and surface pressure and 0.31 for the relative humidity.

The goal of this study is to use satellite, tracer transport model, and meteorological data sets to determine the effects of long-range aerosol transport on cloud microphysics due only to the pollution itself and not to the meteorological state. The focus is on temperature, specific humidity, and LTS since these have been identified as basic meteorological quantities that correlate with cloud microphysical properties (Matsui et al., 2006; Mauger and Norris, 2007). Defining the potential temperature $(\theta)$ as

$\theta=T \cdot\left(\frac{P_{0}}{P}\right)^{\frac{R}{c_{p}}}$,

where $T$ and $P$ are the air temperature and pressure; $P_{0}$ equals $1000 \mathrm{hPa} ; R$ and $c_{p}$ are, respectively, the gas constant for air and the isobaric heat capacity; and the LTS is defined as the potential temperature difference between 700 and $1000 \mathrm{hPa}$ (Klein and Hartmann, 1993).

$\mathrm{LTS}=\theta_{700}-\theta_{1000}$

We also consider clouds with values of LWP greater than $40 \mathrm{~g} \mathrm{~m}^{-2}$ separately from clouds with LWP values less than $40 \mathrm{~g} \mathrm{~m}^{-2}$. This approach separates clouds according to their thermal radiative properties since a cloud with low LWP will tend to act as a graybody and potentially be radiatively susceptible to pollution at thermal wavelengths (Garrett and Zhao, 2006; Lubin and Vogelmann, 2006; Mauritsen et al., 2011). Thick clouds act as blackbodies, and their longwave radiative properties are determined by temperature only (Garrett and Zhao, 2006; Garrett et al., 2009).

The different data sets used in this article are summarized in Table 1.

\section{Methodology}

This study examines data between 2008 and 2010 over the ocean at latitudes greater than $65^{\circ}$. Passive satellite sensors measure interactions of solar radiation with the atmosphere so as to retrieve cloud microphysical parameters of interest from visible wavelength measurements so analyses are restricted to the period between 1 March and 30 September.

\subsection{Colocation of satellite retrieval and model pollution tracer fields}

CO tracer concentrations from a FLEXPART grid cell are defined as the average between two temporal points, averaged over a spatial box. For example, model $\mathrm{CO}$ concentrations at 03:00 UTC and at the latitude-longitude coordinates of $\left(70^{\circ}\right.$, $80^{\circ}$ ), represent an average over a box between the latitudes of $70-71^{\circ}$ and longitudes of $80-82^{\circ}$ and between $00: 00$ and 03:00 UTC.

For an A-train satellite overpass time of 00:45 UTC, we match space-based retrievals to FLEXPART concentration output at 03:00 UTC representing the average concentration between 00:00 and 03:00 UTC and then linearly interpolate ECMWF meteorological fields to the LTS and specific humidity values for 01:30 UTC.

Here, as with many prior studies looking at aerosol-cloud interactions in the Arctic, we consider only low-level clouds 


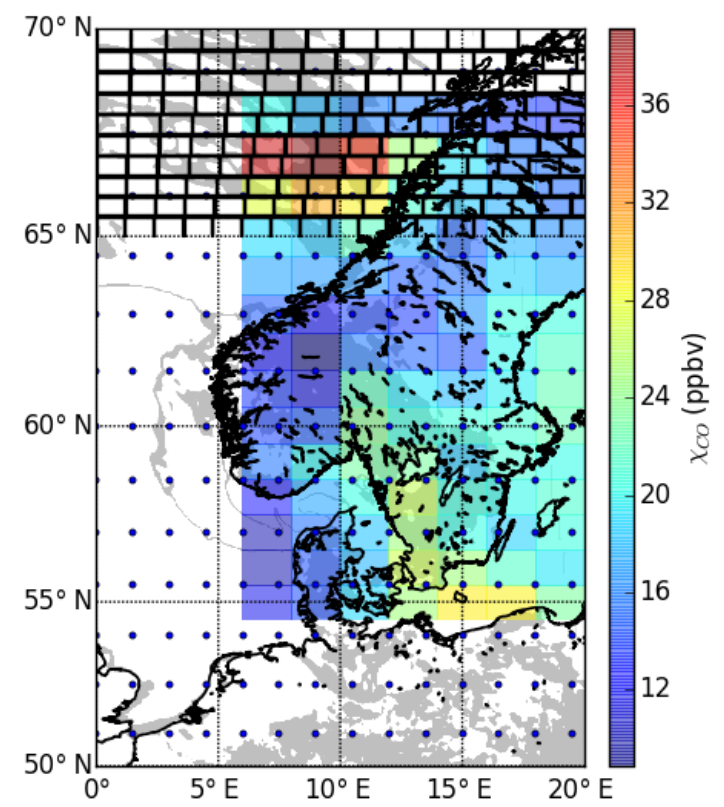

Figure 2. Illustration of the horizontal colocation method, showing satellite data corresponding to cloud top pressures below $1000 \mathrm{~m}$ altitude (gray shading), the average FLEXPART CO concentration between 1 and $2 \mathrm{~km}$ (colored shading), and the spatial resolution of temperature profiles and specific humidity in blue points. The black grid, at the top of the map, corresponds to the sinusoidal equal-area grid used in this study for colocating each data set.

(Garrett et al., 2004; Garrett and Zhao, 2006; Lubin and Vogelmann, 2006; Mauritsen et al., 2011), with POLDER cloud top altitudes between 200 and $1000 \mathrm{~m}$, and between 1000 and $2000 \mathrm{~m}$. The cloud top pressure is translating to cloud top altitude by a pressure profile specific to the Arctic region. These two layers correspond to the FLEXPART vertical bin resolution. We average POLDER and MODIS data that fall within the height bins so that they are colocated with the corresponding FLEXPART CO concentrations.

Regarding horizontal colocation, Fig. 2 shows how the data sets are combined. We project data from satellite, model, and reanalysis data sets onto an equal-area sinusoidal grid such that the grid cell resolution is $0.5^{\circ} \times 0.5^{\circ}$ at the equator corresponding to an area of $54 \mathrm{~km} \times 54 \mathrm{~km}$. The sinusoidal projection conserves the grid cell area independently of longitude and latitude. One grid cell can include up to 81 POLDER-MODIS pixels. Satellite and tracer transport model data are averaged over each grid cell.

One consequence of the averaging is that each grid cell can include up to 81 different pixel-level values of $\Phi$. We place a limit on the SD of the averaged phase index within each grid cell such that $\sigma_{\Phi}<10$ in order to satisfy an a priori requirement of there being a nearly homogeneous phase within each grid cell.

\subsection{The net aerosol-cloud interactions parameter}

Assuming a constant LWC and a monodisperse size distribution of cloud droplets, the droplet effective radius $\left(r_{\mathrm{e}}\right)$ decreases as the CCN number concentration $N_{\mathrm{c}}$ increases following the relation (Feingold et al., 2001)

$$
\left.\frac{\mathrm{d} \ln r_{\mathrm{e}}}{\mathrm{d} \ln N_{\mathrm{c}}}\right|_{\text {LWP }}=-\frac{1}{3} \text {. }
$$

Here, we take a different approach, which is to examine how cloud properties change in response to changes in a $\mathrm{CO}$ tracer under the presumption that the $\mathrm{CO}$ tracer serves as a proxy for the potential of long-range pollution transport, of which CCN may be a part. Of course, $N_{\mathrm{c}}$ and CO tracer concentrations $\left(\chi_{\mathrm{CO}}\right)$ do not represent the same quantity. However, cloud condensation nuclei and $\mathrm{CO}$ are both byproducts of combustion. The two quantities are expected to be highly correlated close to pollution sources where relative changes in one quantity can serve as a proxy for relative changes in the other (Avey et al., 2007; Tietze et al., 2011). The reason for using $\mathrm{CO}$ is 2 -fold. First, $\mathrm{CO}$ is passive and therefor easier to represent in a dynamic model. Second, the analysis here is less focused on the local physics of aerosol-cloud interactions and more focused on the actual impact of anthropogenic activities on clouds far from combustion sources. These are similar but not identical questions. The aerosol-cloud interactions (or the ACI) parameter addresses the precise physics of the extent to which aerosols can modify clouds. However, interactions are a two-way street: when aerosols have been scavenged en route to distant clouds, there is potential for a pollution plume to be present but its impact on cloud properties to be weak. To account for scavenging, we employ the term $\mathrm{ACI}^{\text {net }}$ or the net aerosol-cloud interaction parameter. $\mathrm{ACI}^{\text {net }}$ is the same as the ACI while additionally accounting for any reduction of the ACI due to dry or wet scavenging of aerosols during transport. $\mathrm{ACI}^{\text {net }}$ can be interpreted as a measure of the sensitivity of a cloud at any given location to pollution plumes from distant sources. It allows for the passive components of a plume (e.g., CO) to remain while aerosols have been removed:

$$
\mathrm{ACI}_{\tau}^{\mathrm{net}}=\frac{\mathrm{d} \ln \tau}{\mathrm{d} \ln \chi \mathrm{CO}}
$$

$$
\mathrm{ACI}_{r_{\mathrm{e}}}^{\mathrm{net}}=-\frac{\mathrm{d} \ln r_{\mathrm{e}}}{\mathrm{d} \ln \chi_{\mathrm{CO}}}
$$

For example, in the absence of scavenging, $N_{\mathrm{c}}$ from Eq. (3) is linearly related with $\chi_{\mathrm{CO}}$ and Eq. (5) will be bound by a theoretical maximum value of $\mathrm{ACI}_{r_{\mathrm{e}}}^{\text {net }}=1 / 3$ (Twomey, 1977; Feingold et al., 2001). Further from source regions, the correlation of $\mathrm{CO}$ concentration and aerosols is invariant to dilution but it may be affected by wet and dry scavenging (Garrett et al., 2010, 2011). If scavenging rates are low, $\mathrm{CO}$ and $\mathrm{CCN}$ tend to covary, but when precipitation is high along transport 


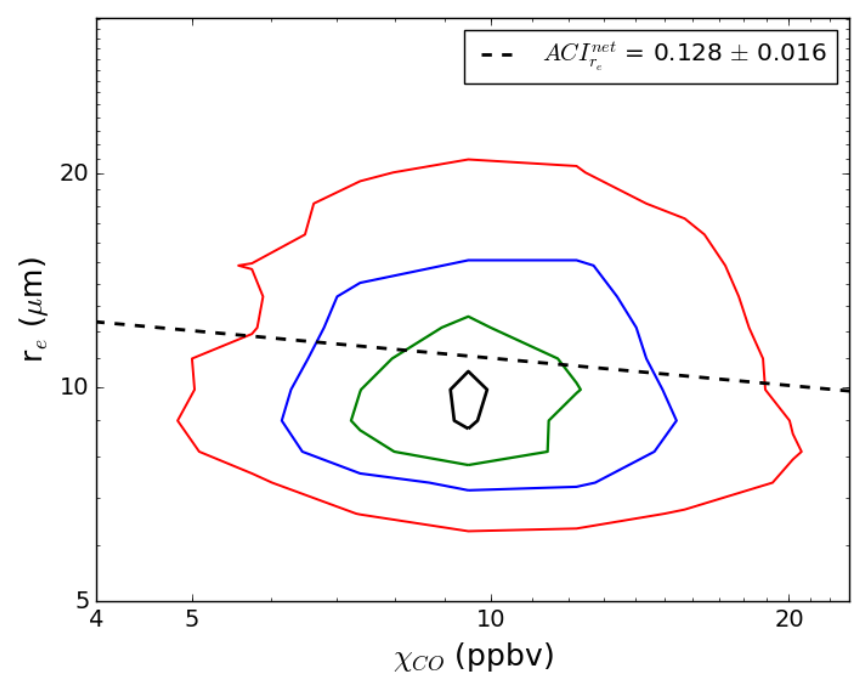

Figure 3. Calculation of the $\mathrm{ACI}_{r_{\mathrm{e}}}^{\text {net }}$ parameter from a probability distribution of values in the effective radius and $\mathrm{CO}$ tracer concentration for liquid clouds with cloud top altitudes between $1000 \mathrm{~m}$ and $2000 \mathrm{~m}$, and cloud top temperatures between -12 and $6{ }^{\circ} \mathrm{C}$. The color scale indicates higher density of values in linear intervals. The $\mathrm{ACI}_{r_{\mathrm{e}}}^{\text {net }}$ number indicates the negative slope of the linear fit (dashed line).

pathways then aerosols are removed and values of $\mathrm{ACI}^{\text {net }}$ will tend to be lower. Garrett et al. (2010) found that in Barrow, Alaska, when the temperature exceeds $4{ }^{\circ} \mathrm{C}$ at the surface, wet scavenging efficiently removes $\mathrm{CCN}$ from the atmosphere. In this event, cloud microphysical properties will not affected by pollution plumes.

Since $r_{\mathrm{e}}$ and the optical depth $(\tau)$ are linked through $\tau=$ $\frac{3}{2} \frac{\mathrm{LWP}}{\rho_{\mathrm{w}} r_{\mathrm{e}}}$ for homogeneous clouds, it follows that

$\frac{\mathrm{d} \ln \tau}{\mathrm{d} \ln \chi_{\mathrm{CO}}}=-\frac{\mathrm{d} \ln r_{\mathrm{e}}}{\mathrm{d} \ln \chi_{\mathrm{CO}}}+\frac{\mathrm{d} \ln L W P}{\mathrm{~d} \ln \chi_{\mathrm{CO}}}$

or,

$\mathrm{ACI}_{\tau}^{\text {net }}=\mathrm{ACI}_{r_{\mathrm{e}}}^{\mathrm{net}}+\mathrm{ACI}_{\mathrm{LWP}}^{\mathrm{net}}$.

Figure 3 shows an example of how $\mathrm{ACI}^{\text {net }}$ is calculated for temperatures between -12 and $6{ }^{\circ} \mathrm{C}$ and altitudes between 1000 and $2000 \mathrm{~m}$, for all LWP values. We first calculate $\mathrm{ACI}_{r_{\mathrm{e}}}^{\text {net }}$ as the linear fit of the natural logarithm of the effective radius to the natural logarithm of $\mathrm{CO}$ concentrations. The fit used in this study is based on the robust linear method (RLM) (Huber, 1973, 1981; Venables and Ripley, 2013). RLM uses an iterative least-squares algorithm: every measurement has initially the same weight; the weights of each point are updated, giving a lower weight to points that appear as outliers with respect to the entire data set. The process iterates several times and stops when the convergence tolerance of the estimated fitting coefficients lies below $10^{-8}$. The slope is therefore less sensitive to outlier points. In Fig. 3, points indicated by the red line are weighted similarly to those indicated by

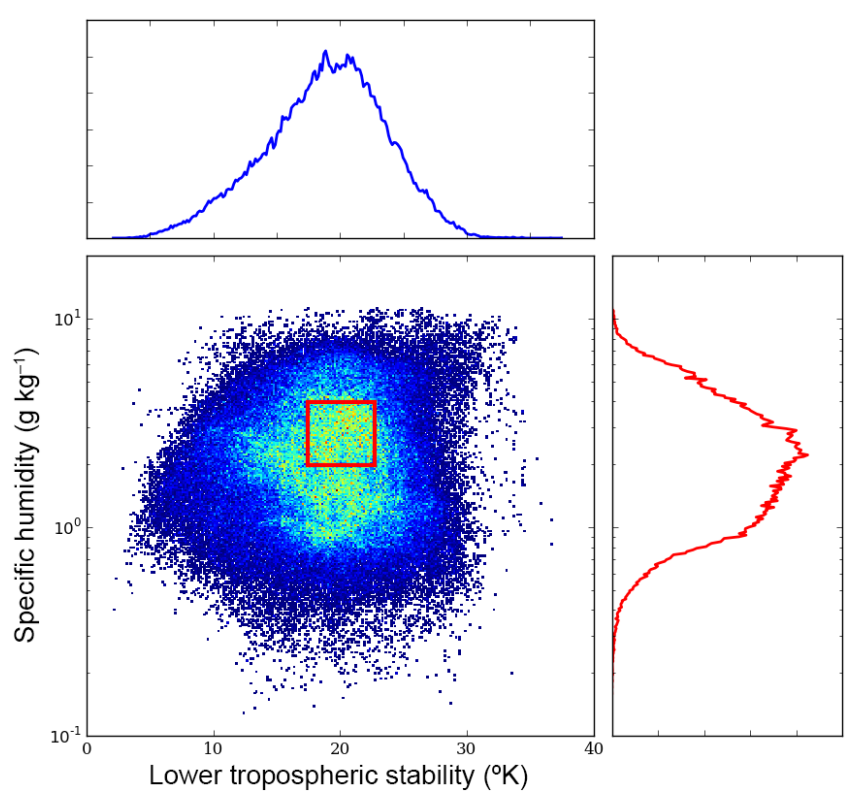

Figure 4. A 2-D histogram of the specific humidity and the LTS retrieved by ECMWF reanalysis from 2008 to 2010 . The red rectangle corresponds to the range where there is a maximum of measurements within a bin corresponding to $15 \%$ of the total range length of the corresponding parameter.

Table 2. Summary of the different ranges of the logarithm of the specific humidity and the LTS over the region of interest, detailing the method used to determine the final range of parameters considered. The $\Delta$ defines the difference between the maximum and the minimum of the total range. The considered range is chosen to keep the maximum number of measurements within a fixed interval of $15 \%$ of the range, corresponding to the red square on Fig. 4.

\begin{tabular}{lll}
\hline & $\log _{10}$ (specific humidity) & LTS $\left(^{\circ}\right)$ \\
\hline Total range [min, max $]$ & {$[-0.89,1.0]$} & {$[2.1,38]$} \\
$\Delta$ total range & 1.9 & 36 \\
$15 \%$ interval & 0.28 & 5.4 \\
Stratified range [min, max $]$ & {$[0.30,0.60]$} & {$[17,22]$} \\
& $=[2.0,4.0]\left(\mathrm{g} \mathrm{kg}^{-1}\right)$ & \\
\hline
\end{tabular}

black and blue lines. The slope retrieved by the linear fit, in Fig. 3 , is $-0.13 \pm 0.016$. Referring to Eq. (5), $\mathrm{ACI}_{r_{\mathrm{e}}}^{\text {net }}$ equals $+0.13 \pm 0.016$.

\subsection{Stratifying the data for specific humidity and lower tropospheric stability}

Figure 4 presents a 2-D histogram of frequency distribution of the specific humidity and the LTS. The LTS ranges from 2.1 to $37 \mathrm{~K}$ and the specific humidity from 0.13 to $11 \mathrm{~g} \mathrm{~kg}^{-1}$. The median values for specific humidity and LTS are $2.0 \mathrm{~g} \mathrm{~kg}^{-1}$ and $19 \mathrm{~K}$, respectively.

Table 2 describes the method used here to stratify the data set according to meteorological conditions. We identify 


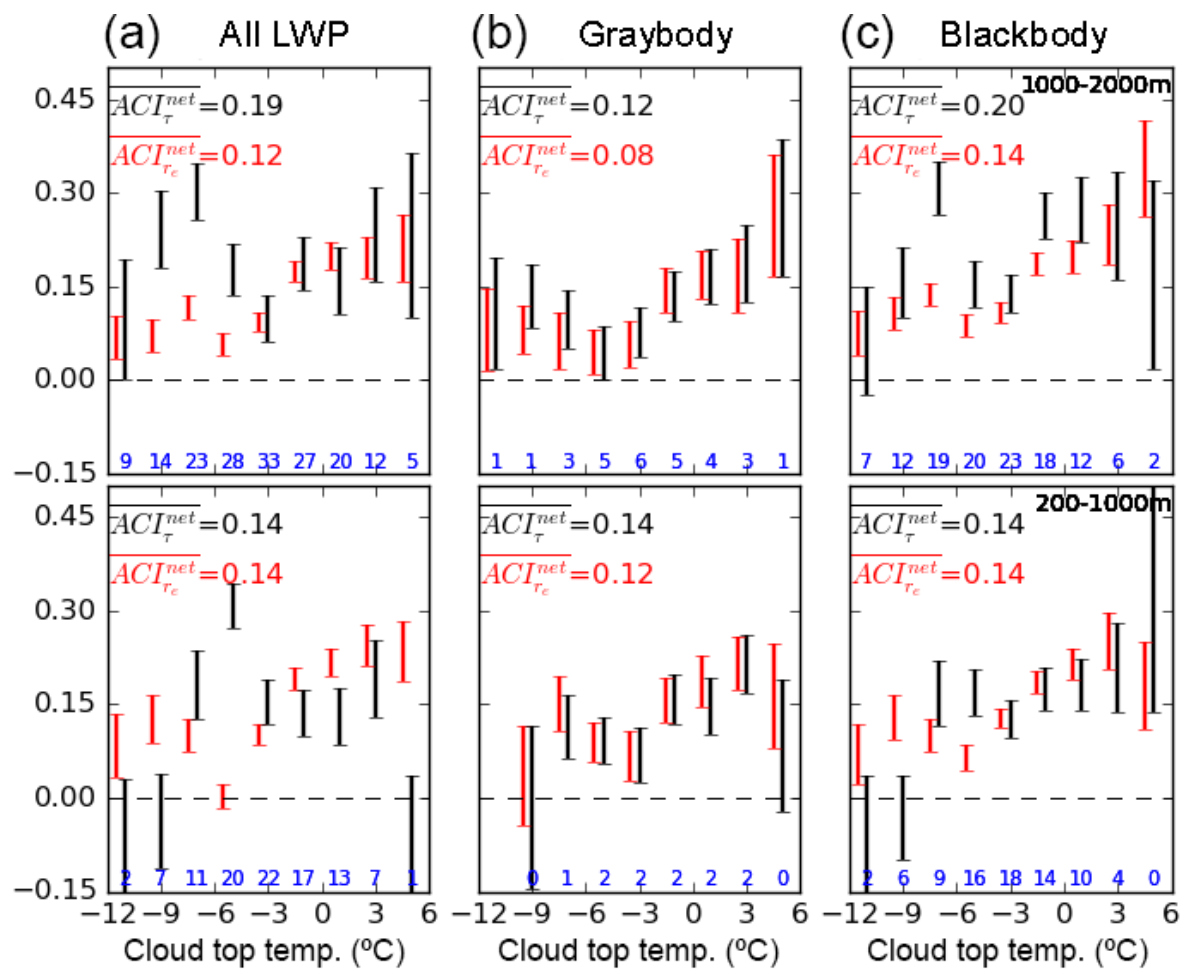

Figure 5. $\mathrm{ACI}^{\text {net }}$ parameter of the effective radius $\left(r_{\mathrm{e}}\right)$ (red) and optical depth $(\tau)$ (black), as a function of temperature calculated for liquid clouds between 200-1000 $\mathrm{m}$ (lower row) and 1000-2000 $\mathrm{m}$ (upper row). The bars indicate the $95 \%$ confidence limit in the calculation of the mean $\mathrm{ACI}^{\text {net }}$ value. Each column corresponds to different thresholds for LWP (blackbody: LWP $>40 \mathrm{~g} \mathrm{~m}^{-2}$, graybody: $\mathrm{LWP}_{<} 40 \mathrm{~g} \mathrm{~m}^{-2}$ ). Blue numbers indicate the number of grid cells, in hundreds, that are used to calculate each $\mathrm{ACI}^{\text {net }}$ value. In each figure the $\mathrm{ACI}^{\text {net }}$ value averaged over the temperature and weighted according to the inverse of the uncertainty is indicated.

a range in LTS and specific humidity that occupies $15 \%$ of the total space of observed values but that is centered at the mode of the respective distributions. The total LTS range is $2.1-37 \mathrm{~K}$, so the interval size is $5.3 \mathrm{~K}$. The specific humidity is distributed over several orders of magnitude. To better represent the distribution, we use a logarithmic scale for this parameter. The logarithm base 10 of specific humidity has an interval of 0.28 . The most common values of meteorological state, defined here as the maximum number of measurements, is delimited by the red rectangle in Fig. 4. The rectangle corresponds to a range of 2.0 to $4.0 \mathrm{~g} \mathrm{~kg}^{-1}$ for specific humidity, and a range of 16.5 to $21.8 \mathrm{~K}$ for LTS. It is these ranges that are focused on for calculation of the $\mathrm{ACI}^{\text {net }}$ parameter. We assume these intervals are sufficiently narrow that the variability within the interval has limited impact on cloud microphysics.

\section{Results}

\subsection{Net aerosol-cloud interactions}

Figure 5 summarizes $\mathrm{ACI}^{\text {net }}$ values calculated using combined POLDER-3, MODIS, and FLEXPART data for the period between 2008 and 2010 for latitudes greater than $65^{\circ}$ over the ocean, stratifying the data set by cloud top temperature in bins of $2^{\circ}$ between -12 and $6^{\circ} \mathrm{C}$. The results are categorized according to bins in temperature, altitude and LWP, and LTS and specific humidity stratified. The number of grid cells used to calculate each $\mathrm{ACI}^{\text {net }}$ parameter per bin ranges from 100 to 3300 . The $\mathrm{ACI}^{\text {net }}$ parameter is almost always positive but sometimes close to zero. $\mathrm{ACI}_{r_{e}}^{\text {net }}$ ranges from 0 for graybody clouds between 1000 and $2000 \mathrm{~m}$ altitude with a cloud top temperature between -6 and $-4{ }^{\circ} \mathrm{C}$, to 0.34 for blackbody clouds between 1000 and $2000 \mathrm{~m}$ altitude with a cloud top temperature between 4 and $6{ }^{\circ} \mathrm{C}$. $\mathrm{ACI}_{\tau}^{\text {net }}$ ranges from -0.10 for all clouds between 200 and $1000 \mathrm{~m}$ altitude with a cloud top temperature of $-11^{\circ} \mathrm{C}$, to 0.35 at $3{ }^{\circ} \mathrm{C}$ for blackbody clouds between 1000 and $2000 \mathrm{~m}$ altitude. In general, $\mathrm{ACI}_{\tau}^{\text {net }}$ and $\mathrm{ACI}_{r_{\mathrm{e}}}^{\text {net }}$ are of the same order of magnitude and the maximum values of $\mathrm{ACI}^{\text {net }}$ are found for clouds with temperatures above the freezing temperature.

We define the uncertainty in $\mathrm{ACI}^{\text {net }}$ as the $95 \%$ confidence limit in the calculation of the slope of the linear fit. The uncertainty in the calculated values of $\mathrm{ACI}_{r_{\mathrm{e}}}^{\text {net }}$ is generally less than 0.1 , except for clouds with temperatures between 4 and $6^{\circ} \mathrm{C}$ and between -12 and $-10^{\circ} \mathrm{C}$, where the uncertainty bar is approximately 0.2 . For the optical depth, the uncer- 
Table 3. ACI $^{\text {net }}$ parameter calculated for the optical depth and the effective radius considering all clouds, graybody clouds, and blackbody clouds, averaged from values presented in Fig. 5 and weighted considering the inverse of the uncertainty in the mean.

\begin{tabular}{llll}
\hline & All LWP & Graybody & Blackbody \\
\hline $\mathrm{ACI}_{r}^{\text {net }}$ & 0.12 & 0.10 & 0.14 \\
$\mathrm{ACI}_{\tau}^{\text {net }}$ & 0.16 & 0.13 & 0.17 \\
\hline
\end{tabular}

tainty is typically approximately 0.1 , although larger values are observed for high and low cloud top temperatures.

For blackbody clouds between 1000 and $2000 \mathrm{~m}$ altitude, the average values of $\mathrm{ACI}_{\tau}^{\text {net }}$ and $\mathrm{ACI}_{r_{\mathrm{e}}}^{\text {net }}$ equal 0.20 and 0.14 , respectively. For cloud tops between 200 and $1000 \mathrm{~m}$ altitude, $\mathrm{ACI}_{\tau}^{\text {net }}$ and $\mathrm{ACI}_{r_{\mathrm{e}}}^{\text {net }}$ equal 0.14 . For graybody clouds between 1000 and $2000 \mathrm{~m}, \mathrm{ACI}_{\tau}^{\text {net }}$ and $\mathrm{ACI}_{r_{\mathrm{e}}}^{\text {net }}$ equal 0.12 and 0.08 , respectively. For cloud tops between 200 and $1000 \mathrm{~m}$ altitude, $\mathrm{ACI}_{\tau}^{\text {net }}$ and $\mathrm{ACI}_{r_{\mathrm{e}}}^{\text {net }}$ equals 0.14 and 0.12 , respectively. Thus, the value of $\mathrm{ACI}^{\text {net }}$ appears to be fairly robust to altitude and cloud thickness and to whether $r_{\mathrm{e}}$ or $\tau$ is considered. Table 3 presents the average $\mathrm{ACI}_{\tau}^{\text {net }}$ and $\mathrm{ACI}_{r_{\mathrm{e}}}^{\text {net }}$. For all cases, $\mathrm{ACI}^{\text {net }}$ values are near $0.13 \pm 0.03$.

\subsection{Dependence of $\mathrm{ACI}^{\text {net }}$ on pollution concentration, specific humidity, and lower tropospheric stability}

In what follows, we examine the influence of LTS, specific humidity, and pollution concentration on $\mathrm{ACI}^{\text {net }}$. Table 4 shows values of $\mathrm{ACI}_{r_{\mathrm{e}}}^{\text {net }}$ and $\mathrm{ACI}_{\tau}^{\text {net }}$ for graybody and blackbody clouds, and for $\chi_{\mathrm{CO}}<5.5 \mathrm{ppbv}$ and $\chi_{\mathrm{CO}}>10.0 \mathrm{ppbv}$, corresponding respectively to the lower and upper quartile of $\mathrm{CO}$ tracer concentration, and for a range in LTS and specific humidity. For graybody and blackbody clouds, $\mathrm{ACI}_{\tau}^{\text {net }}$ and $\mathrm{ACI}_{r_{\mathrm{e}}}^{\text {net }}$ are highest for low values of $\chi_{\mathrm{CO}}$. The difference in $\mathrm{ACI}^{\text {net }}$ values between low and high polluted environments is slightly greater for $\mathrm{ACI}_{r_{\mathrm{e}}}^{\text {net }}$ than for $\mathrm{ACI}_{\tau}^{\text {net }}$. Table 4 suggests that cloud-droplet effective radius and cloud optical depth are most sensitive to pollution when pollution concentrations are low. Previous studies have hypothesized that the effect of $\mathrm{CCN}$ on cloud microphysical properties saturates when cloud-droplet concentrations are high (Bréon et al., 2002; Andersen and Cermak, 2015). This effect does not explain the differences presented in Table 4 because Eqs. (4) and (5) already take into account the potential for linear saturation by considering the logarithms of $\chi_{\mathrm{CO}}$ and cloud parameters.

We now present the sensitivity of the $\mathrm{ACI}^{\text {net }}$ parameter to five different ranges of meteorological parameters delimited by the percentiles values presented in Table 5 . We do not stratify the data according to LWP. Figures 6 and 7 show the influence of pollution loading on the cloud-droplet effective radius and cloud optical depth for each of the different specific humidity and LTS regimes. Figure 6 presents the ACI ${ }^{\text {net }}$ parameter with respect to the cloud optical depth and cloud-
Table 4. $\mathrm{ACI}^{\text {net }}$ parameter calculated for the optical depth and the effective radius considering all clouds, graybody clouds, and blackbody clouds, for two different regimes of $\mathrm{CO}$ concentration representing lower and upper quartiles of $\mathrm{CO}$ concentration.

\begin{tabular}{lll|ll|ll}
\hline & \multicolumn{2}{c|}{ All LWP } & \multicolumn{2}{c}{ Graybody } & \multicolumn{2}{c}{ Blackbody } \\
\cline { 2 - 7 } & $\mathrm{ACI}_{r_{\mathrm{e}}}^{\text {net }}$ & $\mathrm{ACI}_{\tau}^{\text {net }}$ & $\mathrm{ACI}_{r_{\mathrm{e}}}^{\text {net }}$ & $\mathrm{ACI}_{\tau}^{\text {net }}$ & $\mathrm{ACI}_{r_{\mathrm{e}}}^{\text {net }}$ & $\mathrm{ACI}_{\tau}^{\text {net }}$ \\
\hline$\chi_{\mathrm{CO}}<5.5 \mathrm{ppbv}$ & 0.23 & 0.36 & 0.31 & 0.26 & 0.28 & 0.24 \\
$\chi_{\mathrm{CO}}>10 \mathrm{ppbv}$ & 0.09 & 0.35 & 0.09 & 0.16 & 0.14 & 0.16 \\
\hline
\end{tabular}

Table 5. Percentile values of specific humidity and LTS used to defined different regimes of the meteorological parameters.

\begin{tabular}{lll}
\hline & Specific humidity $\left(\mathrm{g} \mathrm{kg}^{-1}\right)$ & LTS $(\mathrm{K})$ \\
\hline Minimum & 0.13 & 2.1 \\
20th percentile & 1.2 & 14 \\
40th percentile & 1.7 & 18 \\
60th percentile & 2.4 & 20 \\
80th percentile & 3.6 & 23 \\
Maximum & 11 & 37 \\
\hline
\end{tabular}

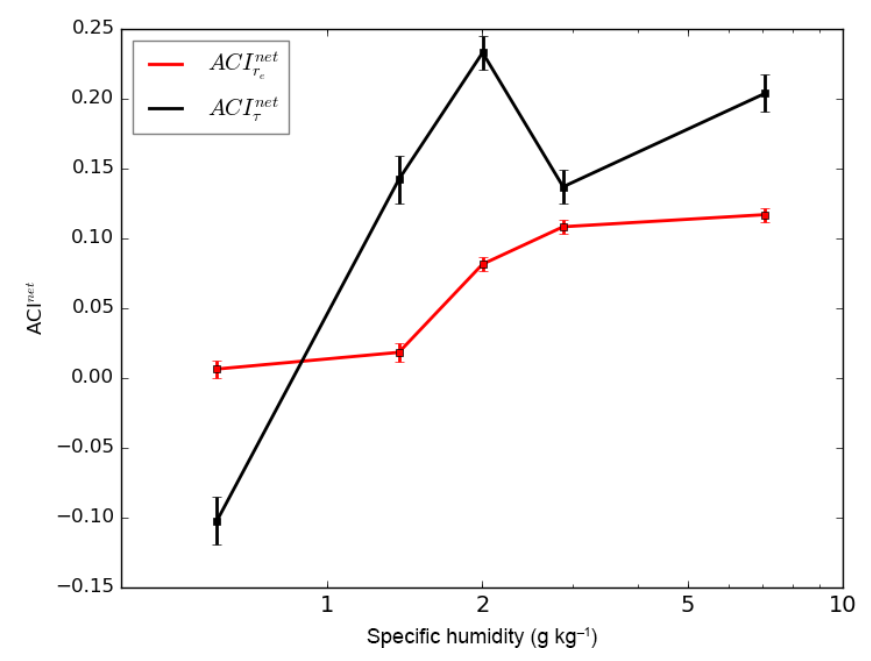

Figure 6. $\mathrm{ACI}_{r_{\mathrm{e}}}^{\text {net }}$ (red) and $\mathrm{ACI}_{\tau}^{\text {net }}$ (black) for different bins of the specific humidity, stratified by LTS between 17 and $22 \mathrm{~K}$. Each marker is placed in the middle of the corresponding bin.

droplet effective radius as a function of the specific humidity, stratifying the data by LTS according to the method described in Sect. 3.3. Figure 7 is the same as Fig. 6 except that it shows $\mathrm{ACI}^{\text {net }}$ as a function of LTS for a range of specific humidities.

Figure 6 shows that $\mathrm{ACI}_{r_{\mathrm{e}}}^{\text {net }}$ and $\mathrm{ACI}_{\tau}^{\text {net }}$ tend to increase with the specific humidity independent of LTS. The ACI ${ }^{\text {net }}$ parameter is close to zero, or negative, for low values of specific humidity. It increases rapidly with specific humidity, saturating at a maximum value of about $2.5 \mathrm{~g} \mathrm{~kg}^{-1}$. We note that cloud top temperature and specific humidity are weakly correlated. The correlation coefficient $\left(r^{2}\right)$ of the linear re- 


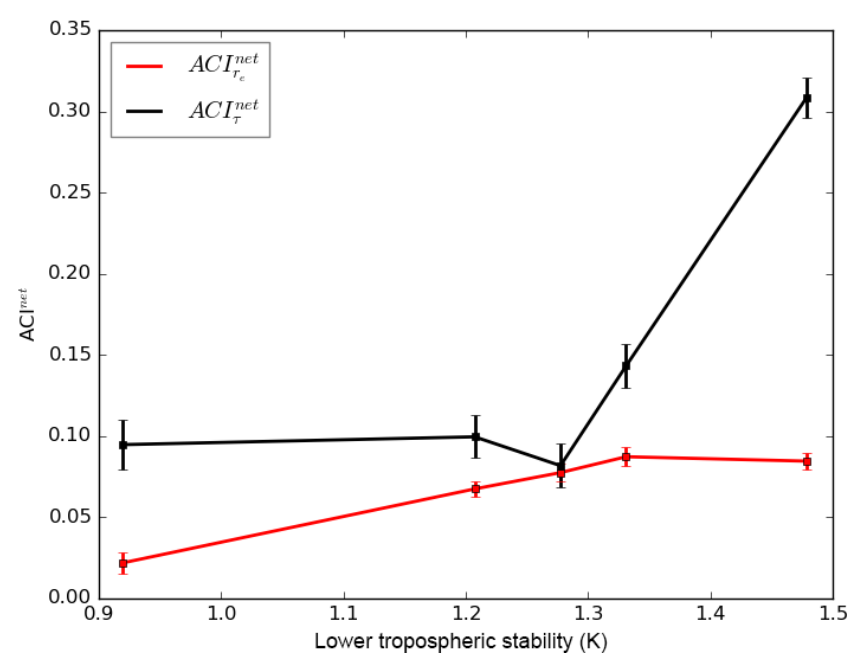

Figure 7. $\mathrm{ACI}_{r_{\mathrm{e}}}^{\text {net }}(\mathrm{red})$ and $\mathrm{ACI}_{\tau}^{\text {net }}$ (black) and $\mathrm{ACI}_{\tau}^{\text {net }}$ as a function of the lower tropospheric stability, stratified by specific humidity between 2.0 and $4.0 \mathrm{~g} \mathrm{~kg}^{-1}$.

gression of the two parameters is 0.20 . The same applies for the specific humidity and the LWP. The correlation coefficient of the two parameters is 0.05 .

$\mathrm{ACI}_{r_{\mathrm{e}}}^{\text {net }}$ increases with LTS from 0.02 for values of LTS ranging between 2.1 and $14 \mathrm{~K}$ to 0.09 for values of LTS between 23 and $38 \mathrm{~K}$. The $\mathrm{ACI}_{\tau}^{\text {net }}$ dependence on LTS is larger: $\mathrm{ACI}_{\tau}^{\text {net }}$ equals 0.10 for LTS values between 2.1 and $14 \mathrm{~K}$ and it equals 0.32 for LTS values between 21 and $38 \mathrm{~K}$.

\section{Discussion}

The results presented here show values of the $\mathrm{ACI}^{\text {net }}$ parameter with respect to the cloud-droplet effective radius and optical depth, for clouds over oceans north of $65^{\circ}$ lying between 200 and $2000 \mathrm{~m}$, and for the years between 2008 and 2010 . We find $\mathrm{ACI}^{\text {net }}$ values that range from 0.00 to 0.34 for the cloud-droplet effective radius, and from -0.10 to 0.35 for the optical depth.

Prior studies examining the Arctic region have retrieved ACI values ranging from -0.10 to 0.40 (Garrett et al., 2004; Lihavainen et al., 2009; Zhao et al., 2012, Sporre et al., 2012). Tietze et al. (2011) calculated $\mathrm{ACI}^{\text {net }}$ values ranging from 0.00 to 0.17 using a similar satellite-FLEXPART colocation method. What differs in this study is that we examine solely anthropogenic pollution, and that we extend the data set from 1 year to 3 years, stratifying the data set according to specific humidity and LTS. The larger $\mathrm{ACI}^{\text {net }}$ values we find in this study suggest a higher sensitivity of cloud microphysical properties to pollution plumes from distant sources than was found by Tietze et al. (2011).

However, Tietze et al. (2011) also found values of $\mathrm{ACI}_{\tau}^{\text {net }}$ that were greater than $\mathrm{ACI}_{r_{\mathrm{e}}}^{\text {net }}$ by a factor of 4 , and they attributed this difference to unknown dynamic or precipitation
Table 6. Difference between $\mathrm{ACI}_{\tau}^{\text {net }}$ and $\mathrm{ACI}_{r_{\mathrm{e}}}^{\text {net }}$ (i.e., $\mathrm{ACI}_{\mathrm{LWP}}^{\text {net }}$ ) for graybody, blackbody, and all clouds when lower tropospheric stability and specific humidity are stratified and when they are not stratified. The averaged $\mathrm{ACI}^{\text {net }}$ values are shown in Table 3 .

\begin{tabular}{llll}
\hline & All LWP & Graybody & Blackbody \\
\hline Stratified & 0.04 & 0.03 & 0.04 \\
Not stratified & 0.12 & 0.04 & 0.08 \\
\hline
\end{tabular}

feedbacks that make $\mathrm{ACI}_{\mathrm{LWP}}^{\text {net }}$ greater than zero (Eq. 7). In contrast, our results show that the $\mathrm{ACI}_{r_{\mathrm{e}}}^{\text {net }}$ and $\mathrm{ACI}_{\tau}^{\text {net }}$ parameters are more similar, suggesting no such feedback. Table 6 compares the differences between $\mathrm{ACI}_{\tau}^{\text {net }}$ and $\mathrm{ACI}_{r_{\mathrm{e}}}^{\text {net }}$ that are presented in Table 3, along with their corresponding values when no control is made for specific humidity and LTS. The difference between $\mathrm{ACI}_{r_{\mathrm{e}}}^{\text {net }}$ and $\mathrm{ACI}_{\tau}^{\text {net }}$ is largest when meteorological parameters are not controlled for. For all clouds considered, the maximum difference increases from 0.04 when the data are considered within narrow meteorological bands to 0.12 when the data are not. This result is important since it suggests that the hypothesized feedbacks discussed by Tietze et al. (2011) may have in fact been due to the natural sensitivity of clouds to local meteorology. Not controlling sufficiently for meteorology may lead to artifacts that exaggerate the magnitude of the aerosol indirect effect.

In contrast to most prior efforts, satellite-retrieved cloud properties are not compared to $\mathrm{CCN}$ or aerosol concentrations but rather to pollution concentrations - specifically $\mathrm{CO}$ simulated from a tracer transport model. CO serves as a proxy for $\mathrm{CCN}$ close to pollution sources although far from sources $\mathrm{CCN}$ and $\mathrm{CO}$ can become decoupled due to scavenging en route to distant clouds. The comparison we present through the $\mathrm{ACI}^{\text {net }}$ parameter implicitly accounts for this possibility. For temperatures below $-6^{\circ} \mathrm{C}$, low values of $\mathrm{ACI}^{\text {net }}$ are observed. Tietze et al. (2011) hypothesized that at such temperatures, cloud supersaturations may be too small to activate aerosols as $\mathrm{CCN}$ or that clouds with lower temperatures have followed longer transport pathways nearer to the surface (Stohl, 2006) and therefore had greater exposure to dry deposition.

Table 4 suggests that $\mathrm{ACI}^{\text {net }}$ values are lowest when pollution concentrations are high. Figure 8 presents the normalized distribution of potential temperature for polluted and pristine clouds, defined as the upper and lower quartile for graybody clouds. We present results for graybody clouds because the $\mathrm{ACI}^{\text {net }}$ differences between polluted and clean cases are largest; results for blackbody and all clouds are not shown here, but have similar results regarding the potential temperature distribution.

Highly polluted air parcels are associated with potential temperatures around $280 \mathrm{~K}$ whereas pristine air parcels have a lower potential temperature - around $272 \mathrm{~K}$. We hypothesize that higher values of potential temperature suggest pol- 


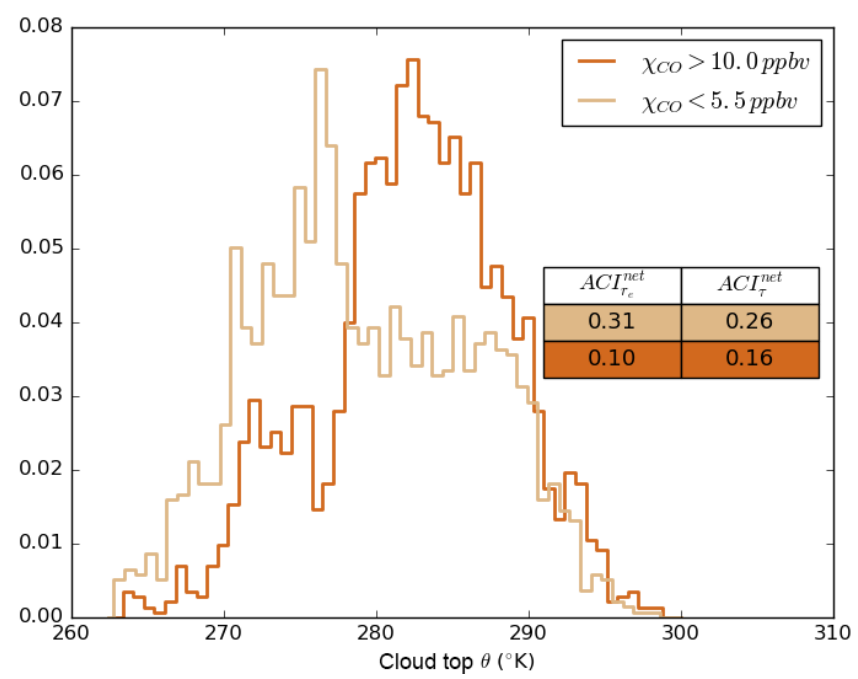

Figure 8. Normalized distribution of the cloud top potential temperature when clouds are associated with $\mathrm{CO}$ tracer concentrations $\left(\chi_{\mathrm{CO}}\right)$ greater than $10 \mathrm{ppbv}$ and less than $5 \mathrm{ppbv}$. The values of $\mathrm{ACI}_{r_{\mathrm{e}}}^{\text {net }}$ and $\mathrm{ACI}_{\tau}^{\text {net }}$ associated with each histogram are presented also in Table 3.

lution sources from further south, so wet scavenging is more likely to occur during transport; this decreases the correlation between a $\mathrm{CO}$ tracer and $\mathrm{CCN}$, therefore lowering the $\mathrm{ACI}^{\text {net }}$ parameter. Also, polluted air parcel and aerosols do not necessarily have the same physical and chemical properties at lower and higher latitudes, and this difference may impact the influence of aerosols on cloud microphysics and aerosols (Bilde and Svenningsson, 2004; Dusek et al., 2006; Ervens et al., 2007; Andreae and Rosenfeld, 2008).

In general, we observe that when moisture increases, the cloud sensitivity to pollution increases. From model simulations of stratocumulus, Ackerman et al. (2004) found that when the relative humidity $(\mathrm{RH})$ above cloud top is high, cloud LWP increases with $N_{\mathrm{c}}$ consistent with theoretical arguments (Albrecht, 1989; Pincus and Baker, 1994), but that when the RH is low, the LWP decreases when $N_{\mathrm{c}}$ increases, as supported by some observations (Coakley and Walsh, 2002). The difference was attributed to the consequence of dry air into a cloud layer. Humidity inversions are common above low-level cloud tops in the Arctic (Nygärd et al., 2014), so similar phenomena may be playing a role.

Studies of the indirect effect at midlatitudes suggest that values of ACI are highest under unstable conditions (Chen et al., 2014; Andersen and Cermak, 2015). Our results from the Arctic show the reverse, that conditions of high LTS are associated with higher values of $\mathrm{ACI}^{\text {net }}$. Klein and Hartmann (1993) showed that, in general, higher values of LTS lead to greater stratiform cloudiness, except in the Arctic where radiative cooling prevails over convection as the driving mechanism for cloud formation. This result is similar to results found by Kim et al. (2008) who found that aerosol-cloud in- teractions are strongest in clouds with adiabatic liquid water content profiles. Such clouds might be expected more frequently when LTS is high and there is reduced vertical mixing.

Finally, we find $\mathrm{ACI}_{\tau}^{\text {net }}$ is more sensitive to changes in LTS than $\mathrm{ACI}_{r_{\mathrm{e}}}^{\text {net }}$. A consequence is that for values of LTS greater than $23 \mathrm{~K}, \mathrm{ACI}_{\tau}^{\text {net }}$ and $\mathrm{ACI}_{r_{\mathrm{e}}}^{\text {net }}$ differ by about 0.20 . In a stable atmosphere with high LTS it appears that $\mathrm{ACI}_{\mathrm{LWP}}^{\text {net }}$ increases more strongly in response to aerosols than in unstable environments (Klein and Hartmann, 1993; Qiu et al., 2015).

\section{Conclusions}

Satellite, numerical model, and meteorological reanalysis data sets from 2008 to 2010 are used here to calculate the sensitivity of cloud-droplet effective radius and optical depth in the Arctic to anthropogenic pollution transported from midlatitudes. We focused on latitudes north of $65^{\circ}$ for a period between March 2008 and October 2010. Using ECMWF reanalysis data, we stratified the data set according to temperature, LTS, specific humidity, altitude, and LWP. We find that the sensitivity of cloud properties to pollution, as quantified by values of $\mathrm{ACI}^{\text {net }}$, lies close to a theoretical maximum value of $1 / 3$, assuming that a simulated $\mathrm{CO}$ tracer correlates well with $\mathrm{CCN}$. Further, $\mathrm{ACI}_{r_{\mathrm{e}}}^{\text {net }}$ and $\mathrm{ACI}_{\tau}^{\text {net }}$ seem to increase with specific humidity and LTS, highlighting that meteorological parameters have an important impact on aerosolcloud interactions.

Globally, Klimont et al. (2013) have estimated that there was a drop of about $9281 \mathrm{Gg}$ in anthropogenic sulphur dioxide emissions between 2005 and 2010 due to a reduction in European and American emissions and a flue gas desulfurization program on power plants in China. This reduction in emissions has led to a decrease of sulfate concentrations at the Arctic surface station (Hirdman et al., 2010). In the Arctic, the effect of a decrease in midlatitude pollution emissions may someday be offset by greater levels of Arctic industrialization (Lindholt and Glomsrød, 2012) and shipping (Pizzolato et al., 2014; Miller and Ruiz, 2014) that introduce new local aerosol sources. Further, an increase in the extent of open ocean due to sea-ice retreat may be expected to lead to an increase in the atmospheric humidity (Boisvert and Stroeve, 2015) and from the results presented here, a higher sensitivity of clouds to aerosols. However, this study also suggests that any associated decrease in LTS could partially counter-act this effect.

Climate warming is thought to stimulate boreal forest fires (Westerling et al., 2006). The impact of pollution from biomass burning has not been included in the present research. Given biomass burning aerosol can act as efficient ice nuclei (Markus et al., 2009), the analyses presented here might be extended to explore aerosol-induced changes in cloud thermodynamic phase. 
Acknowledgements. This paper is dedicated posthumously to Kyle Tietze, who developed many of the techniques used in this study while a graduate student at the University of Utah. We thank two anonymous reviewers and Graham Feingold for constructive comments on the manuscript. The authors thank ICARE, NASA, and CNES for the data used in this research. We acknowledge financial support from The University of Lille. This material is based upon work supported by the National Science Foundation under the Grant No. 1303965. NILU researchers have received funding from the European Union Seventh Framework Programme (FP7/2007-2013) under grant agreement no. 282688 - ECLIPSE.

Edited by: G. Feingold

\section{References}

Ackerman, A. S., Kirkpatrick, M. P., Stevens, D. E., and Toon, O. B.: The impact of humidity above stratiform clouds on indirect aerosol climate forcing, Nature, 432, 1014-1017, doi:10.1038/nature03137.1, 2004.

Albrecht, B. A.: Aerosols, Cloud Microphysics, and Fractional Cloudiness, Science, 245, 1227-1230, 1989.

Amann, M., Bertok, I., Borken-Kleefeld, J., Cofala, J., Heyes, C., Höglund-Isaksson, L., Klimont, Z., Nguyen, B., Posch, M., Rafaj, P., Sandler, R., Schöpp, W., Wagner, F., and Winiwarter, W.: Cost-effective control of air quality and greenhouse gases in Europe: Modeling and policy applications, Environ. Modell. Softw., 26, 1489-1501, doi:10.1016/j.envsoft.2011.07.012, 2011.

Ancellet, G., Pelon, J., Blanchard, Y., Quennehen, B., Bazureau, A., Law, K. S., and Schwarzenboeck, A.: Transport of aerosol to the Arctic: analysis of CALIOP and French aircraft data during the spring 2008 POLARCAT campaign, Atmos. Chem. Phys., 14, 8235-8254, doi:10.5194/acp-14-8235-2014, 2014.

Andersen, H. and Cermak, J.: How thermodynamic environments control stratocumulus microphysics and interactions with aerosols, Environ. Res. Lett., 10, 24004, doi:10.1088/17489326/10/2/024004, 2015.

Andreae, M. O. and Rosenfeld, D.: Aerosol-cloudprecipitation interactions, Part 1 . The nature and sources of cloud-active aerosols, Earth-Sci. Rev., 89, 13-41, doi:10.1016/j.earscirev.2008.03.001, 2008.

Avey, L., Garrett, T. J., and Stohl, A.: Evaluation of the aerosol indirect effect using satellite, tracer transport model, and aircraft data from the International Consortium for Atmospheric Research on Transport and Transformation, J. Geophys. Res.-Atmos., 112, 110, doi:10.1029/2006JD007581, 2007.

Belchansky, G. I., Douglas, D. C., and Platonov, N. G.: Duration of the Arctic sea ice melt season: Regional and interannual variability, 1979-2001, J. Climate, 17, 67-80, doi:10.1175/15200442(2004)017<0067:DOTASI>2.0.CO;2, 2004.

Berg, L. K., Berkowitz, C. M., Barnard, J. C., Senum, G., and Springston, S. R.: Observations of the first aerosol indirect effect in shallow cumuli, Geophys. Res. Lett., 38, L03809, doi:10.1029/2010GL046047, 2011.

Berrisford, P., Dee, D., Fielding, K., Fuentes, M., Kallberg, P., Kobayashi, S., and Uppala, S.: The ERA-Interim Archive, ECMWF, Reading, UK, 1, available at: http://old.ecmwf.int/ publications/library/do/references/list/782009 (last access: 11 November 2015), 2009.

Bilde, M. and Svenningsson, B.: CCN activation of slightly soluble organics: The importance of small amounts of inorganic salt and particle phase, Tellus B, 56, 128-134, doi:10.1111/j.16000889.2004.00090.x, 2004.

Boisvert, L. N. and Stroeve, J. C.: The Arctic is becoming warmer and wetter as revealed by the Atmospheric Infrared Sounder, Geophys. Res. Lett., 42, 4439-4446, doi:10.1002/2015GL063775, 2015.

Brenguier, J. and Wood, R.: Observational strategies from the micro to meso scale, in: Clouds in the Perturbed Climate System: Their Relationship to Energy Balance, Atmospheric Dynamics, and Precipitation, edited by: Heintzenberg, J. and Charlson, R. J., 487-510, available at: ftp://ftp-projects.zmaw.de/aerocom/ meetings/frankfurt_2007/brenguier.pdf (last access: 11 November 2015), MIT Press, MASS, Cambridge, 2009.

Bréon, F.-M. and Colzy, S.: Cloud detection from the spaceborne POLDER instrument and validation against surface synoptic observations, J. Appl. Meteorol., 38, 777-785, doi:10.1175/15200450(1999)038<0777:CDFTSP>2.0.CO;2, 1999.

Bréon, F.-M., Tanré, D., and Generoso, S.: Aerosol effect on cloud droplet size monitored from satellite, Science (New York, N. Y.), 295, 834-8, doi:10.1126/science.1066434, 2002.

Buriez, J. C., Vanbauce, C., Parol, F., Goloub, P., Herman, M., Bonnel, B., Fouquart, Y., Couvert, P., and Seze, G.: Cloud detection and derivation of cloud properties from POLDER, Int. J. Remote Sens., 18, 2785-2813, doi:10.1080/014311697217332, 1997.

Chang, F. L. and Coakley, J. A.: Relationships between marine stratus cloud optical depth and temperature: Inferences from AVHRR observations, J. Climate, 20, 2022-2036, doi:10.1175/JCLI4115.1, 2007.

Chen, Y.-C., Christensen, M. W., Stephens, G. L., and Seinfeld, J. H.: Satellite-based estimate of global aerosol-cloud radiative forcing by marine warm clouds, Nat. Geosci., advance on, 7, 643-646, doi:10.1038/ngeo2214, 2014.

Coakley, J. A. and Walsh, C. D.: Limits to the aerosol indirect radiative effect derived from observations of ship tracks, J. Atmos. Sci., 59, 668-680, doi:10.1175/1520 0469(2002)059<0668:LTTAIR>2.0.CO;2, 2002.

Costantino, L. and Bréon, F. M.: Aerosol indirect effect on warm clouds over South-East Atlantic, from co-located MODIS and CALIPSO observations, Atmos. Chem. Phys., 13, 69-88, doi:10.5194/acp-13-69-2013, 2013.

Dee, D. P., Uppala, S. M., Simmons, A. J., Berrisford, P., Poli, P., Kobayashi, S., Andrae, U., Balmaseda, M. A., Balsamo, G., Bauer, P., Bechtold, P., Beljaars, A. C. M., van de Berg, L., Bidlot, J., Bormann, N., Delsol, C., Dragani, R., Fuentes, M., Geer, A. J., Haimberger, L., Healy, S. B., Hersbach, H., Hólm, E. V., Isaksen, L., Kållberg, P., Köhler, M., Matricardi, M., Mcnally, A. P., Monge-Sanz, B. M., Morcrette, J. J., Park, B. K., Peubey, C., de Rosnay, P., Tavolato, C., Thépaut, J. N., and Vitart, F.: The ERA-Interim reanalysis: Configuration and performance of the data assimilation system, Q. J. Roy. Meteorol. Soc., 137, 553-597, doi:10.1002/qj.828, 2011.

Desmons, M., Ferlay, N., Parol, F., Mcharek, L., and Vanbauce, C.: Improved information about the vertical location and extent of monolayer clouds from POLDER3 measurements in the oxygen 
A-band, Atmos. Meas. Tech., 6, 2221-2238, doi:10.5194/amt-62221-2013, 2013.

Dusek, U., Frank, G. P., Hildebrandt, L., Curtius, J., Schneider, J., Walter, S., Chand, D., Drewnick, F., Hings, S., Jung, D., Borrmann, S., and Andreae, M. O.: Size matters more than chemistry for cloud-nucleating ability of aerosol particles, Science (New York, N. Y.), 312, 1375-1378, doi:10.1126/science.1125261, 2006.

Eckhardt, S., Quennehen, B., Olivié, D. J. L., Berntsen, T. K., Cherian, R., Christensen, J. H., Collins, W., Crepinsek, S., Daskalakis, N., Flanner, M., Herber, A., Heyes, C., Hodnebrog, Ø., Huang, L., Kanakidou, M., Klimont, Z., Langner, J., Law, K. S., Lund, M. T., Mahmood, R., Massling, A., Myriokefalitakis, S., Nielsen, I. E., Nøjgaard, J. K., Quaas, J., Quinn, P. K., Raut, J.-C., Rumbold, S. T., Schulz, M., Sharma, S., Skeie, R. B., Skov, H., Uttal, T., von Salzen, K., and Stohl, A.: Current model capabilities for simulating black carbon and sulfate concentrations in the Arctic atmosphere: a multi-model evaluation using a comprehensive measurement data set, Atmos. Chem. Phys., 15, 9413-9433, doi:10.5194/acp-15-9413-2015, 2015.

Ervens, B., Cubison, M., Andrews, E., Feingold, G., Ogren, J. A., Jimenez, J. L., DeCarlo, P., and Nenes, A.: Prediction of cloud condensation nucleus number concentration using measurements of aerosol size distributions and composition and light scattering enhancement due to humidity, J. Geophys. Res.-Atmos., 112, 115, doi:10.1029/2006JD007426, 2007.

Feingold, G.: Modeling of the first indirect effect: Analysis of measurement requirements, Geophys. Res. Lett., 30, 30, 1997, doi:10.1029/2003GL017967, 2003a.

Feingold, G.: First measurements of the Twomey indirect effect using ground-based remote sensors, Geophys. Res. Lett., 30, 1922, doi:10.1029/2002GL016633, 2003b.

Feingold, G., Remer, L. A., Ramaprasad, J., and Kaufman, Y. J.: Analysis of smoke impact on clouds in Brazilian biomass burning regions: An extension of Twomey's approach, J. Geophys. Res., 106, 22907-22922, 2001.

Fougnie, B., Bracco, G., Lafrance, B., Ruffel, C., Hagolle, O., and Tinel, C.: PARASOL in-flight calibration and performance, Appl. Optics, 46, 5435-5451, doi:10.1364/AO.46.005435, 2007.

Garrett, T. J. and Zhao, C.: Increased Arctic cloud longwave emissivity associated with pollution from mid-latitudes, Nature 440, 787-789, doi:10.1038/nature04636, 2006.

Garrett, T. J., Radke, L. F., and Hobbs, P. V.: Aerosol Effects on Cloud Emissivity and Surface Longwave Heating in the Arctic, J. Atmos. Sci., 59, 769-778, doi:10.1175/15200469(2002)059<0769:AEOCEA>2.0.CO;2, 2002.

Garrett, T. J., Zhao, C., Dong, X., Mace, G. G., and Hobbs, P. V.: Effects of varying aerosol regimes on low-level Arctic stratus, Geophys. Res. Lett., 31, L17105, doi:10.1029/2004GL019928, 2004.

Garrett, T. J., Maestras, M. M., Krueger, S. K., and Shmidt, C. T.: Acceleration by aerosol of a radiative-thermodynamic cloud feedback influencing Arctic surface warming, Geophys. Res. Lett., 36, L19804, doi:10.1029/2009GL040195, 2009.

Garrett, T. J., Zhao, C., and Novelli, P. C.: Assessing the relative contributions of transport efficiency and scavenging to seasonal variability in Arctic aerosol, Tellus B, 62, 190-196, doi:10.1111/j.1600-0889.2010.00453.x, 2010.
Garrett, T. J., Brattström, S., Sharma, S., Worthy, D. E. J., and Novelli, P.: The role of scavenging in the seasonal transport of black carbon and sulfate to the Arctic, Geophys. Res. Lett., 38, L16805, doi:10.1029/2011GL048221, 2011.

Hirdman, D., Sodemann, H., Eckhardt, S., Burkhart, J. F., Jefferson, A., Mefford, T., Quinn, P. K., Sharma, S., Ström, J., and Stohl, A.: Source identification of short-lived air pollutants in the Arctic using statistical analysis of measurement data and particle dispersion model output, Atmos. Chem. Phys., 10, 669-693, doi:10.5194/acp-10-669-2010, 2010.

Huber, P. J.: The 1972 Wald memorial lectures: robust regression: asymptotics, conjectures, and Monte Carlo, The Annals of Statistics, 1, 799-821, 1973.

Huber, P. J.: Robust Statistics, John Wiley and Sons, Inc., New York, 1981.

Ji, R., Jin, M., and Varpe, Ø.: Sea ice phenology and timing of primary production pulses in the Arctic Ocean, Glob. Change Biol., 19, 734-741, doi:10.1111/gcb.12074, 2013.

Kaufman, Y. J., Koren, I., Remer, L. A., Rosenfeld, D., and Rudich, Y.: The effect of smoke, dust, and pollution aerosol on shallow cloud development over the Atlantic Ocean, P. Natl. Acad. Sci. USA, 102, 11207-11212, doi:10.1073/pnas.0505191102, 2005.

Kawamoto, K., Hayasaka, T., Uno, I., and Ohara, T.: A correlative study on the relationship between modeled anthropogenic aerosol concentration and satellite-observed cloud properties over east Asia, J. Geophys. Res.-Atmos., 111, 1-7, doi:10.1029/2005JD006919, 2006.

Kim, B. G., Miller, M. A., Schwartz, S. E., Liu, Y., and Min, Q.: The role of adiabaticity in the aerosol first indirect effect, J. Geophys. Res.-Atmos., 113, 1-13, doi:10.1029/2007JD008961, 2008.

King, M. D. and Platnick, S.: Collection 005 change summary for the MODIS cloud optical property (06 _ OD) algorithm high impact change overview: change details:, Terra, 1, 1-23, 2006.

Klein, S. A. and Hartmann, D. L.: The seasonal cycle of low stratiform clouds, J. Climate, 6, 1587-1606, 1993.

Klimont, Z., Smith, S. J., and Cofala, J.: The last decade of global anthropogenic sulfur dioxide: 2000-2011 emissions, Environ. Res. Lett., 8, 014003, doi:10.1088/1748-9326/8/1/014003, 2013.

Klimont, Z., Hoglund, L., Heyes, C., Rafaj, P., Schoepp, W., Cofala, J., Borken-Kleefeld, J., Purohit, P., Kupiainen, K., Winiwarter, W., Amann, M., Zhao, B., Wang, S. X., Bertok, I., and Sander, R.: Global scenarios of air pollutants and methane: 1990-2050, in preparation, 2016.

Lance, S., Shupe, M. D., Feingold, G., Brock, C. A., Cozic, J., Holloway, J. S., Moore, R. H., Nenes, A., Schwarz, J. P., Spackman, J. R., Froyd, K. D., Murphy, D. M., Brioude, J., Cooper, O. R., Stohl, A., and Burkhart, J. F.: Cloud condensation nuclei as a modulator of ice processes in Arctic mixed-phase clouds, Atmos. Chem. Phys., 11, 8003-8015, doi:10.5194/acp-11-80032011, 2011.

Law, K. S. and Stohl, A.: Arctic air pollution: origins and impacts, Science (New York, N. Y.), 315, 1537-40, doi:10.1126/science.1137695, 2007.

Law, K. S., Stohl, A., Quinn, P. K., Brock, C., Burkhart, J., Paris, J. D., Ancellet, G., Singh, H. B., Roiger, A., Schlager, H., Dibb, J., Jacob, D. J., Arnold, S. R., Pelon, J., and Thomas, J. L.: Arctic air pollution: new insights from POLARCAT-IPY, B. 
Am. Meteorol. Soc., 95, 1873-1895, doi:10.1175/BAMS-D-1300017.1, 2014.

Lihavainen, H., Kerminen, V. M., and Remer, L. A.: Aerosol-cloud interaction determined by both in situ and satellite data over a northern high-latitude site, Atmos. Chem. Phys., 10, 1098710995, doi:10.5194/acp-10-10987-2010, 2009.

Lindholt, L. and Glomsrød, S.: The Arctic: No big bonanza for the global petroleum industry, Energ. Econ., 34, 1465-1474, doi:10.1016/j.eneco.2012.06.020, 2012.

Lohmann, U. and Feichter, J.: Global indirect aerosol effects: a review, Atmos. Chem. Phys., 5, 715-737, doi:10.5194/acp-5-7152005, 2005.

Longley, I. D., Inglis, D. W. F., Gallagher, M. W., Williams, P. I., Allan, J. D., and Coe, H.: Using $\mathrm{NO}_{x}$ and $\mathrm{CO}$ monitoring data to indicate fine aerosol number concentrations and emission factors in three UK conurbations, Atmos. Environ., 39, 5157-5169, doi:10.1016/j.atmosenv.2005.05.017, 2005.

Lubin, D. and Vogelmann, A. M.: A climatologically significant aerosol longwave indirect effect in the Arctic, Nature, 439, 453456, doi:10.1038/nature04449, 2006.

Lubin, D. and Vogelmann, A. M.: Expected magnitude of the aerosol shortwave indirect effect in springtime Arctic liquid water clouds, Geophys. Res. Lett., 34, L11801, doi:10.1029/2006GL028750, 2007.

Markus, T., Stroeve, J. C., and Miller, J.: Recent changes in Arctic sea ice melt onset, freezeup, and melt season length, J. Geophys. Res.-Oceans, 114, 1-14, doi:10.1029/2009JC005436, 2009.

Matsui, T., Masunaga, H., Kreidenweis, S. M., Pielke, R. A., Tao, W. K., Chin, M., and Kaufman, Y. J.: Satellite-based assessment of marine low cloud variability associated with aerosol, atmospheric stability, and the diurnal cycle, J. Geophys. Res.Atmos., 111, 1-16, doi:10.1029/2005JD006097, 2006.

Mauger, G. S. and Norris, J. R.: Meteorological bias in satellite estimates of aerosol-cloud relationships, Geophys. Res. Lett., 34, 1-5, doi:10.1029/2007GL029952, 2007.

Mauritsen, T., Sedlar, J., Tjernström, M., Leck, C., Martin, M., Shupe, M., Sjogren, S., Sierau, B., Persson, P. O. G., Brooks, I. M., and Swietlicki, E.: An Arctic CCN-limited cloud-aerosol regime, Atmos. Chem. Phys., 11, 165-173, doi:10.5194/acp-11165-2011, 2011.

Miller, A. W. and Ruiz, G. M.: Arctic shipping and marine invaders, Nature Clim. Change, 4, 413-416, doi:10.1038/nclimate2244, 2014.

Myhre, G., Stordal, F., Johnsrud, M., Kaufman, Y. J., Rosenfeld, D., Storelvmo, T., Kristjansson, J. E., Berntsen, T. K., Myhre, A., and Isaksen, I. S. A.: Aerosol-cloud interaction inferred from MODIS satellite data and global aerosol models, Atmos. Chem. Phys., 7, 3081-3101, doi:10.5194/acp-7-3081-2007, 2007.

Nakajima, T., Higurashi, A., Kawamoto, K., and Penner, J. E.: A possible correlation between satellite-derived cloud and aerosol microphysical parameters, Geophys. Res. Lett., 28, 1171-1174, doi:10.1029/2000GL012186, 2001.

Nygärd, T., Valkonen, T., and Vihma, T.: Characteristics of arctic low-tropospheric humidity inversions based on radio soundings, Atmos. Chem. Phys., 14, 1959-1971, doi:10.5194/acp-14-19592014, 2014.

Overland, J. E. and Wang, M.: When will the summer Arctic be nearly sea ice free?, Geophys. Res. Lett., 40, 2097-2101, doi:10.1002/grl.50316, 2013.
Painemal, D., Kato, S., and Minnis, P.: Boundary layer regulation in the southeast Atlantic cloud microphysics during the biomass burning season as seen by the A-train satellite constellation, J. Geophys. Res.-Atmos., 119, 11288-11302, doi:10.1002/2014JD022182, 2014.

Paris, J.-D., Stohl, A., Nédélec, P., Arshinov, M. Yu., Panchenko, M. V., Shmargunov, V. P., Law, K. S., Belan, B. D., and Ciais, P.: Wildfire smoke in the Siberian Arctic in summer: source characterization and plume evolution from airborne measurements, Atmos. Chem. Phys., 9, 9315-9327, doi:10.5194/acp-9-9315-2009, 2009.

Pincus, R. and Baker, M. B.: Effect of precipitation on the albedo susceptibility of clouds in the marine boundary layer, Nature, 372, 250-252, doi:10.1038/372250a0, 1994.

Pizzolato, L., Howell, S. E. L., Derksen, C., Dawson, J., and Copland, L.: Changing sea ice conditions and marine transportation activity in Canadian Arctic waters between 1990 and 2012, Climatic Change, 123, 161-173, doi:10.1007/s10584-013-1038-3, 2014.

Platnick, S., King, M. D., Ackerman, S. A., Menzel, W. P., Baum, B. A., Riédi, J. C., and Frey, R. A.: The MODIS cloud products: Algorithms and examples from terra, IEEE T. Geosci. Remote, 41, 459-472, doi:10.1109/TGRS.2002.808301, 2003.

Qiu, S., Dong, X., Xi, B., and Li, J. F.: Characterizing Arctic mixedphase cloud structure and its relationship with humidity and temperature inversion using ARM NSA observations, J. Geophys. Res., 120, 7737-7746, doi:10.1002/2014JD023022, 2015.

Quinn, P. K., Shaw, G., Andrews, E., Dutton, E. G., RuohoAirola, T., and Gong, S. L.: Arctic haze: Current trends and knowledge gaps, Tellus B, 59, 99-114, doi:10.1111/j.16000889.2006.00238.x, 2007.

Richter-Menge, J. and Jeffries, M.: State of the climate in 2010: The Arctic, B. Am. Meteorol. Soc., 92, S143-S160, 2011.

Riedi, J., Marchant, B., Platnick, S., Baum, B. A., Thieuleux, F., Oudard, C., Parol, F., Nicolas, J.-M., and Dubuisson, P.: Cloud thermodynamic phase inferred from merged POLDER and MODIS data, Atmos. Chem. Phys., 10, 11851-11865, doi:10.5194/acp-10-11851-2010, 2010.

Schwartz, S. E., Harshvardhan, and Benkovitz, C. M.: Influence of anthropogenic aerosol on cloud optical depth and albedo shown by satellite measurements and chemical transport modeling, P. Natl. Acad. Sci. USA, 99, 1784-1789, doi:10.1073/pnas.261712099, 2002.

Sekiguchi, M.: A study of the direct and indirect effects of aerosols using global satellite data sets of aerosol and cloud parameters, J. Geophys. Res., 108, 1-15, doi:10.1029/2002JD003359, 2003.

Serreze, M. C. and Francis, J. A.: The Arctic on the fast track of change, Weather, 61, 65-69, doi:10.1256/wea.197.05, 2006.

Serreze, M. C., Barrett, A. P., Stroeve, J. C., Kindig, D. N., and Holland, M. M.: The emergence of surface-based Arctic amplification, The Cryosphere, 3, 11-19, doi:10.5194/tc-3-11-2009, 2009.

Shaw, G. E.: The arctic haze phenomenon, B. Am. Meteorol. Soc., 76, 2403-2413, doi:10.1175/15200477(1995)076<2403:TAHP>2.0.CO;2, 1995.

Shindell, D. T., Chin, M., Dentener, F., Doherty, R. M., Faluvegi, G., Fiore, A. M., Hess, P., Koch, D. M., MacKenzie, I. A., Sanderson, M. G., Schultz, M. G., Schulz, M., Stevenson, D. S., Teich, H., Textor, C., Wild, O., Bergmann, D. J., Bey, I., Bian, H., Cuvelier, C., Duncan, B. N., Folberth, G., Horowitz, L. W., Jonson, J., 
Kaminski, J. W., Marmer, E., Park, R., Pringle, K. J., Schroeder, S., Szopa, S., Takemura, T., Zeng, G., Keating, T. J., and Zuber, A.: A multi-model assessment of pollution transport to the Arctic, Atmos. Chem. Phys., 8, 5353-5372, doi:10.5194/acp-85353-2008, 2008.

Sirois, A. and Barrie, L. A.: Arctic lower tropospheric aerosol trends and composition at Alert, Canada: 1980-1995, J. Geophys. Res., 104, 11599, doi:10.1029/1999JD900077, 1999.

Sodemann, H., Pommier, M., Arnold, S. R., Monks, S. A., Stebel, K., Burkhart, J. F., Hair, J. W., Diskin, G. S., Clerbaux, C., Coheur, P.-F., Hurtmans, D., Schlager, H., Blechschmidt, A.-M., Kristjánsson, J. E., and Stohl, A.: Episodes of cross-polar transport in the Arctic troposphere during July 2008 as seen from models, satellite, and aircraft observations, Atmos. Chem. Phys., 11, 3631-3651, doi:10.5194/acp-11-3631-2011, 2011.

Sporre, M. K., Glantz, P., Tunved, P., Swietlicki, E., Kulmala, M., and Lihavainen, H.: A study of the indirect aerosol effect on subarctic marine liquid low-level clouds using MODIS cloud data and ground-based aerosol measurements, Atmos. Res., 116, 5666, doi:10.1016/j.atmosres.2011.09.014, 2012.

Stephens, G. L., Vane, D. G., Boain, R. J., Mace, G. G., Sassen, K., Wang, Z., Illingworth, A. J., O’Connor, E. J., Rossow, W. B., Durden, S. L., Miller, S. D., Austin, R. T., Benedetti, A., and Mitrescu, C.: The cloudsat mission and the A-Train: A new dimension of space-based observations of clouds and precipitation, B. Am. Meteorol. Soc., 83, 1771-1790+1742, doi:10.1175/BAMS-83-12-1771, 2002.

Stohl, A.: Characteristics of atmospheric transport into the Arctic troposphere, J. Geophys. Res., 111, D11306, doi:10.1029/2005JD006888, 2006.

Stohl, A., Hittenberger, M., and Wotawa, G.: Validation of the lagrangian particle dispersion model FLEXPART against largescale tracer experiment data, Atmos. Environ., 32, 4245-4264, doi:10.1016/S1352-2310(98)00184-8, 1998.

Stohl, A., Forster, C., Frank, A., Seibert, P., and Wotawa, G.: Technical note: The Lagrangian particle dispersion model FLEXPART version 6.2, Atmos. Chem. Phys., 5, 2461-2474, doi:10.5194/acp-5-2461-2005, 2005.

Stohl, A., Berg, T., Burkhart, J. F., Fjǽraa, A. M., Forster, C., Herber, A., Hov, Ø., Lunder, C., McMillan, W. W., Oltmans, S., Shiobara, M., Simpson, D., Solberg, S., Stebel, K., Ström, J., Tørseth, K., Treffeisen, R., Virkkunen, K., and Yttri, K. E.: Arctic smoke - record high air pollution levels in the European Arctic due to agricultural fires in Eastern Europe in spring 2006, Atmos. Chem. Phys., 7, 511-534, doi:10.5194/acp-7-511-2007, 2007.

Stohl, A., Klimont, Z., Eckhardt, S., Kupiainen, K., Shevchenko, V. P., Kopeikin, V. M., and Novigatsky, A. N.: Black carbon in the Arctic: the underestimated role of gas flaring and residential combustion emissions, Atmos. Chem. Phys., 13, 8833-8855, doi:10.5194/acp-13-8833-2013, 2013.

Stohl, A., Aamaas, B., Amann, M., Baker, L. H., Bellouin, N., Berntsen, T. K., Boucher, O., Cherian, R., Collins, W., Daskalakis, N., Dusinska, M., Eckhardt, S., Fuglestvedt, J. S., Harju, M., Heyes, C., Hodnebrog, Ø., Hao, J., Im, U., Kanakidou, M., Klimont, Z., Kupiainen, K., Law, K. S., Lund, M. T., Maas, R., MacIntosh, C. R., Myhre, G., Myriokefalitakis, S., Olivié, D., Quaas, J., Quennehen, B., Raut, J.-C., Rumbold, S. T., Samset, B. H., Schulz, M., Seland, Ø., Shine, K. P., Skeie, R. B., Wang, S., Yttri, K. E., and Zhu, T.: Evaluating the climate and air qual- ity impacts of short-lived pollutants, Atmos. Chem. Phys., 15, 10529-10566, doi:10.5194/acp-15-10529-2015, 2015.

Tietze, K., Riedi, J., Stohl, A., and Garrett, T. J.: Space-based evaluation of interactions between aerosols and low-level Arctic clouds during the Spring and Summer of 2008, Atmos. Chem. Phys., 11, 3359-3373, doi:10.5194/acp-11-3359-2011, 2011.

Twomey, S.: The influence of Pollution on the shortwave Albedo of Clouds, J. Atmos. Sci., 34, 1149-1152,doi:10.1175/15200469(1977)034<1149:TIOPOT>2.0.CO;2 1977.

Venables, W. N. and Ripley, B. D.: Modern Applied Statistics with S-PLUS, Springer Science and Business Media, New York, NY, 2013.

Wang, F., Guo, J., Wu, Y., Zhang, X., Deng, M., Li, X., Zhang, J., and Zhao, J.: Satellite observed aerosol-induced variability in warm cloud properties under different meteorological conditions over eastern China, Atmos. Environ., 84, 122-132, doi:10.1016/j.atmosenv.2013.11.018, 2014.

Warneke, C., Bahreini, R., Brioude, J., Brock, C. A., De Gouw, J. A., Fahey, D. W., Froyd, K. D., Holloway, J. S., Middlebrook, A., Miller, L., Montzka, S., Murphy, D. M., Peischl, J., Ryerson, T. B., Schwarz, J. P., Spademan, J. R., and Veres, P.: Biomass burning in Siberia and Kazakhstan as an important source for haze over the Alaskan Arctic in April 2008, Geophys. Res. Lett., 36, 2-7, doi:10.1029/2008GL036194, 2009.

Weisz, E., Li, J., Menzel, W. P., Heidinger, A. K., Kahn, B. H., and Liu, C. Y.: Comparison of AIRS, MODIS, CloudSat and CALIPSO cloud top height retrievals, Geophys. Res. Lett., 34, 1-5, doi:10.1029/2007GL030676, 2007.

Wesslén, C., Tjernström, M., Bromwich, D. H., De Boer, G., Ekman, A. M. L., Bai, L. S., and Wang, S. H.: The Arctic summer atmosphere: An evaluation of reanalyses using ASCOS data, Atmos. Chem. Phys., 14, 2605-2624, doi:10.5194/acp-14-26052014, 2014.

Westerling, A. L., Hidalgo, H. G., Cayan, D. R., and Swetnam, T. W.: Warming and earlier spring increase western U. S. forest wildfire activity, Science (New York, N. Y.), 313, 940-943, doi:10.1126/science.1128834, 2006.

Yoshimori, M., Watanabe, M., Abe-Ouchi, A., Shiogama, H., and Ogura, T.: Relative contribution of feedback processes to Arctic amplification of temperature change in MIROC GCM, Clim. Dynam., 42, 1613-1630, doi:10.1007/s00382-013-1875-9, 2013.

Zhao, C. and Garrett, T. J.: Effects of Arctic Haze on surface Cloud radiative forcing, Geophys. Res. Lett., 42, 557-564, doi:10.1002/2014GL062015, 2015.

Zhao, C., Klein, S. A., Xie, S., Liu, X., Boyle, J. S., and Zhang, Y.: Aerosol first indirect effects on non-precipitating low-level liquid cloud properties as simulated by CAM5 at ARM sites, Geophys. Res. Lett., 39, 1-7, doi:10.1029/2012GL051213, 2012.

Zygmuntowska, M., Mauritsen, T., Quaas, J., and Kaleschke, L.: Arctic clouds and surface radiation-a critical comparison of satellite retrievals and the ERA-interim reanalysis, Atmos. Chem. Phys., 12, 6667-6677, doi:10.5194/acp-12-6667-2012, 2012. 